\title{
International Diversification and Cost of Debt: Evidence from Korean Debt Market
}

\author{
Xiyu Rong ${ }^{1}$ Myung In Kim ${ }^{1 *}$ Shijie Wang ${ }^{2}$ \\ 1.College of Business Administration, Inha University, South Korea, 2.Beijing, China \\ *Corresponding author: mikim21@inha.ac.kr
}

\begin{abstract}
In this paper, we examine how international diversification affects the cost of debt capital in Korean capital market. In addition, we investigate whether the impact of international diversification on cost of debt capital are affected by 1) analyst coverage as a proxy for information environment and 2) Big 4 accounting firm as a proxy for audit quality. Our empirical results show that international diversification is negatively associated with cost of debt. We also find that the impact of international diversification on cost of debt is working only for firms with analyst coverage and only for firms audited by Big 4 audit firms, suggesting that good information environment and higher audit quality are key factors to allow firms to obtain positive effects of international diversification in Korean debt market.
\end{abstract}

Keywords: International diversification, Cost of debt, Analyst following, Audit quality

DOI: $10.7176 / \mathrm{EJBM} / 11-33-03$

Publication date: November $30^{\text {th }} 2019$

\section{Introduction}

The number of studies investigate the relation between cost of equity and firms' international diversification. From the perspective of cost of debt, however, the association with its degree of international diversification has been relatively rarely discussed. Thus, the objective of this paper is to examine the impact of internationalization on cost of capital. Specifically, this paper investigates whether the degree of international diversification affects cost of debt capital and examine the two factors that could affect the relation between international diversification and cost of debt: information environment and audit quality.

From the perspective of business strategy, international diversification can play a crucial role to improve the competitive advantage and enlarge market share, hence increasing firm value (e.g., Caves, 1971; Hymer, 1976). The imperfections across international markets could motivate firms to do international transitions for potential growth (Eeeunza and Senbet, 1981). On the other hand, several articles reveal the empirical evidence on the negative relation between firm value and the international diversification (Boatsman et al. 1993; Denis et al. 2002; Christophe 2002; etc.). The negative aspects of international diversification can be explained by the extra risks associated with social and political unpredictable movements in overseas markets (Aliber, 1984). Also, Reeb et al. (1998) and $\mathrm{He}$ and $\mathrm{Ng}$ (1998) claim that the additional risks of international business include exchange rate risk and political risk, thus decreasing the firm value. Further, internationalization could increase information asymmetry so that overseas segments become less controllable (Lee and Kwok, 1988).

In this context, this paper examines how international diversification affects the cost of debt capital. In addition, we investigate the two factors, information environment and audit quality, which may affect the effect of international diversification on cost of debt capital. First, we find that international diversification is significantly negatively associated with cost of debt capital, indicating that international diversification provides significant economic effect to reduce the cost of debt capital. Second, we find that the positive economic effect of international diversification on reduction in cost of debt is working only for firms with analysts' coverage, a proxy for good information environment. This highlights the importance of role of the analyst in terms of information environment in capital market in Korea. Third, we also find that the impact of international diversification on cost debt capital is working only for firms that are audited by large accounting firms, Big4. This suggests that audit quality provides a key factor to expect positive effect of international diversification in debt capital market in Korea.

Our research is composed of the following sections: Section 2 reviews relevant literature, Section 3 develops our hypothesis, Section 4 presents data and model, Section 5 reports empirical results, and finally, Section 6 discusses research limitation and concludes our study. 


\section{Literature Review}

\subsection{International diversification}

International diversification is an attempt to add more diversity to take on less risks. As the economic cycles varies across countries, by diversifying investments globally, returns on investment would be more stable than not to do so. Thus, international transactions are regarded as a tool which enables companies to obtain extra value (Caves, 1971; Hymer, 1976). Errunza and Senbet (1981) explain that firms that have ability to obtain benefit from the imperfections of international markets could increase the value of the firms. In this regards, international diversification is perceived as a value-increasing strategy.

There are empirical studies that show the negative perspectives of international diversification. Kinney (1972) argues that higher degree of international diversification could lead to a series of risks embedded in foreign market. From the study conducted by Boatsman et al (1993), the information provided by overseas segments could not be regarded as useful nor reliable for valuation purpose. Denis et al. (2002) observed that using data from 1984 to 1997, earnings on foreign sectors are valued differently in terms of risks, returns, and information quality in comparison with earnings on domestic sectors. Additionally, foreign operations are associated with higher information asymmetry than domestic operations (Thomas 1999; Khurana et al. 2003; Callen et al. 2005; Hope and Thomas 2008). Information on foreign earnings is likely more difficult for investors and other information intermediaries to assess the real risks and returns of the firm. From the perspective of analysts, Duru and Reeb (2002) argue that greater international diversification is associated with less accurate analysts' forecasts. Furthermore, managers are more likely to engage in self-maximizing decision-making in foreign operations because of low levels of monitoring in foreign segments (Hope and Thomas 2008). Consistent with these arguments, Denis et al. (2002) show that geographical diversification is associated with a reduction in firm value.

Nonetheless, international diversification provides benefits to the firms' growth value. This point of view is supported by Bodnar and Weintrop (1997), stating that the earnings response coefficient (ERC) on foreign earnings is larger than the ERC on domestic earnings especially when foreign markets are growing in terms of sales and assets. Thomas (1999) documents that foreign earnings are more persistent than domestic earnings in predicting future performance. From the perspective of debtholders, Mansi and Reeb (2002) observe that corporate diversification is associated with lower shareholder value but with higher debt value as the default risk might be reduced by diversification. Levy and Sarnat (1970) and Lessard (1973) highlight the risk reduction benefit of multinational diversification. Similarly, Agmon and Lessard (1977) argue that multinational corporations have greater stability against volatile markets. Fatemi (1984) reports that internationally diversified firms have lower systematic risk that can be converted into lower cost of equity compared to domestic firms.

\subsection{Cost of debt}

Cost of debt refers to the effective rate a company pays on its current debt. Debt is the source of finance in form of issued bond or long-term notes payable. Debt is regarded as a cheaper source of finance compared to equity. The required rate of return on debt is influenced by various factors in capital market that are widely discussed in literature.

Sanchez-Ballesta and Garcia-Meca (2011) state that cost of debt is affected by ownership concentration and shareholder identity using data from Spain firms. The result illustrates that firms with government ownership enjoy lower cost of debt as the agency cost of debt is reduced by the monitoring on management by banks. Also, information disclosure could be a factor that influences the cost of debt. Datta et al. (1999) state that using a higherquality audits could be a measure for a firm to reduce their interest rates as this action is regarded as a method to develop the firm's reputation. The auditor's reputation can be considered a substitute of the fledgling reputation of firms with short credit histories.

Anderson et al. (2004) show that creditor reliance on accounting-based debt covenants suggests that debtors are concerned with board of director characteristics that potentially affect the integrity of financial accounting reports. They find that the cost of debt is inversely related to board independence and board size, and fully independent audit committees are associated with a significantly lower cost of debt financing. Similarly, yield spreads are also negatively related to audit committee size and meeting frequency. These market-based evidence implies that boards and audit committees are important parties affecting the reliability of financial reports, thus influencing the cost of debt. 


\section{Hypothesis Development}

According to the modern portfolio theory, an investor can construct a portfolio of multiple assets that will maximize returns for a given level of risk. Similarly, multinational firms can diversify its business globally to construct its portfolio aiming to lower the overall risks that results in a lower cost of debt.

The negative relationship between the cost of debt and the degree of internationalization can be explained as follows. First, capital market arbitrage hypothesis raised by Reeb et al. (2001) argue that international firms could create or benefit from the imperfect market and obtain a lower cost of debt due to market segmentation and differing risk prices in various host country markets. Second, corporate international activity could benefit firms in terms of reducing risk. Sharked (1986) presents that international firms operating in multiple markets could increasingly diversify their assets and sources of income which result in lowering earnings volatility. When markets are not perfectly correlated, internationalization of a firm's business can effectively lower the risk of bankruptcy, which leads to a lower cost of capital. Therefore, we hypothesize that the higher degree of international diversification, the lower the cost of debt would be.

Hypothesis 1: International diversification is negatively associated with cost of debt.

Prior studies show that information based on analysts' forecasts plays an important role in mitigating information asymmetry in that analysts have a comparative advantage in interpreting specific industry or market segment trends (e.g., Piostroski and Roulstone, 2004, etc.). Mansi et al. (2004) present that the analysts' forecasting information leads to a lower cost of debt capital, suggesting that analysts are important information intermediaries that help market participants reduce information asymmetry between stockholders and managers. Following prior studies, we posit that firms with more analyst followings are likely to have better information environment. Overseas segments for multinational firms represent severe information problem. In this regards, we posit that the economic effect of international diversification on cost of debt capital is likely to increase when firms are followed by analysts. Thus, the second hypothesis is developed as follows:

Hypothesis 2: The relation between international diversification and cost of debt is more pronounced for firms with analyst following.

Audit quality can be measured by the size of audit firms in the sense that for large auditors, misreporting can bring a significant reputation loss, thus improving audit quality. Thus, the Big4 audit firms, such as KPMG, Ernst \& Young (EY), Deloitt and Pricewaterhouse Coopers ( $\mathrm{PwC}$ ), are considered as providing higher audit quality than other small accounting firms. Francis (2004) argues that firms with greater inherent uncertainty due to greater information asymmetry between the firm and outsiders are likely to hire more credible and high-quality auditor especially when firms are going public. As discussed earlier, internationally diversified firms are more exposed to information asymmetry and uncertainty. Thus, given that hiring Big4 auditor enhances credibility of financial information and improves information quality, the effect of cost of debt for more internationally diversified firms is more pronounced. Thus, our last hypothesis is developed as follows:

Hypothesis 3: The relation between international diversification and cost of debt is more pronounced for firms audited by BIG 4 accounting firms.

\section{Data and Methodology}

\subsection{Data}

This paper would adapt data based on Korean firms. The data are collected from two sources. Analyst forecast data, stock data and financial data are obtained from the Fn Guide 3.0 annual database. The auditor data and financial score data are obtained from the Kis-Value III database.

Firms includes Korean listed firms on KSE and KOSDAQ ranging from 1998 to 2009, excluding firms in financial industry. Firms whose fiscal year ends other than December $31^{\text {st }}$ are excluded. The $1 \%$ of extreme observations in each tail of each variable for each year were excluded. 
Table 1. Descriptive Statistics for the Variables

\begin{tabular}{llllllll}
\hline Variables & \multicolumn{1}{c}{ Std. Dev. } & \multicolumn{1}{c}{ Mean } & \multicolumn{1}{c}{ Maximum } & \multicolumn{1}{c}{ Q3 } & \multicolumn{1}{c}{ Median } & \multicolumn{1}{c}{ Q1 } & \multicolumn{1}{c}{ Minimum } \\
\hline SPREAD & 0.0223 & 0.0271 & 0.1532 & 0.0352 & 0.0183 & 0.0041 & -0.0330 \\
INTDIV & 0.2765 & 0.3071 & 0.9947 & 0.5049 & 0.1369 & 0.0019 & 0.0000 \\
SIZE & 18.5937 & 1.3734 & 23.2739 & 19.2732 & 18.2939 & 17.6106 & 16.2176 \\
LEV & 0.5028 & 0.1690 & 0.9394 & 0.6281 & 0.5013 & 0.3820 & 0.1161 \\
ASSTR & 0.1943 & 0.1280 & 0.6119 & 0.2675 & 0.1691 & 0.0960 & 0.0059 \\
DA & 0.0829 & 0.0772 & 0.4380 & 0.1127 & 0.0603 & 0.0279 & 0.0010 \\
LOSS & 0.2563 & 0.4366 & 1.0000 & 1.0000 & 0.0000 & 0.0000 & 0.0000 \\
ROA & 0.0104 & 0.1043 & 0.2629 & 0.0637 & 0.0265 & -0.0045 & -0.5918 \\
INTCOV & 5.8739 & 17.5593 & 202.4877 & 5.5574 & 1.9727 & 0.4722 & -29.7721 \\
BM & 1.7179 & 1.3227 & 8.1535 & 2.2454 & 1.3554 & 0.7829 & 0.1468 \\
STDRET & 19.2435 & 11.5100 & 82.3424 & 23.3127 & 16.0414 & 11.5303 & 4.7256 \\
MARKET & 0.5178 & 0.4997 & 1.0000 & 1.0000 & 1.0000 & 0.0000 & 0.0000 \\
\hline
\end{tabular}

Variable definition: SPREAD = Difference between interest rate and 3-years-maturity Treasury bond yield in the same year; INTDIV = Foreign sales deflated by total sales; SIZE = The natural log of fiscal-year end total assets of the prior year; LEV= Book value of the sum of short- and long-term debt deflated by total assets; ASSTR = Total property, plant, and equipment deflated by total assets; DA = Absolute discretionary accruals; estimated from modified Jones model; LOSS $=$ an indicator variable, 1 if the net income is negative in the current year, zero otherwise; ROA = Net income deflated by total assets; INTCOV= Operating earnings deflated by interest; $\mathrm{BM}=$ Book value of equity deflated by the market value of equity; STDRET = The standard deviation of monthly stock return during the fiscal year; MARKET = One if the firm listed in KSE, zero if the firm listed in KOSDAQ; YR = Year dummy.

\subsection{Measurement of variables}

According to prior research, there are mainly four ways to measure the degree of International Diversification: i) the percentage of foreign sales to total sales (Sullivan 1994; Duru and Reed 2002; Herrmann et al. 2008.), ii) foreign earnings and domestic earnings (Bondar and Weintrop 1997; Denis et al. 2002.), iii) the percentage of foreign assets to total assets (Reed et al. 1998), and iv) the number of geographical segments where the firm operates (Gomex-Mejia and Phalich 1997; Chin et al. 2009). This paper would adapt the first one to measure the degree of International Diversification due to data availability in Korea;

International Diversification $=\frac{\text { Foreign Sales }}{\text { Total Sales }}$

The dependent variable, the cost of debt, is proxied by SPREAD. This study estimates SPREAD as the difference between interest rate based on firms' annual reports and the 3-year-maturity treasury bond issued in the same year. The calculation of interest rate would be done as follow:

Interest Rate $=\frac{\text { Interest }}{\text { Average short and long debt }}$

Other control variables include the size (SIZE), leverage ratio (LEV), proportion of fixed asset (ASSTR), discretionary accruals (DA), LOSS, return on asset (ROA), interest coverage (INTCOV), book-to-market ratio (BM), and the standard deviation of stock return (STDRET). Also, the two dummy variables, market indicator (KSE or KOSDAQ) and year indicator are included in the model.

The model is established as follow:

$$
\begin{aligned}
& \text { SPREAD }_{t+1}=\alpha_{1}+\beta_{1} \text { INTDIV }_{t}+\beta_{2} \text { SIZE }_{t}+\beta_{3} \text { LEV }_{t}+\beta_{4} \text { ASSTR }_{t}+\beta_{5} \text { DA }_{t}+\beta_{6} \text { LOSS }_{t}+ \\
& \beta_{7} \text { ROA }_{t}+\beta_{8} \text { INTCOV }_{t}+\beta_{9} \text { BM }_{t}+\beta_{10} \text { STDRET }_{t}+\beta_{11} \text { MARKET }_{t}+\Sigma Y R+\varepsilon_{t}
\end{aligned}
$$

where,

$\begin{aligned} \text { SPREAD } & =\text { Difference between interest rate and 3-years-maturity Treasury bond yield in the } \\ \text { same year } & \\ \text { INTDIV } & =\text { Foreign sales deflated by total sales } \\ \text { SIZE } & =\text { The natural log of fiscal-year end total assets of the prior year } \\ \text { LEV } & =\text { Book value of the sum of short- and long-term debt deflated by total assets } \\ \text { ASSTR } & =\text { Total property, plant, and equipment deflated by total assets } \\ \text { DA } & =\text { Absolute discretionary accruals estimated from modified Jones model } \\ \text { LOSS } & =\text { One if the net income is negative in the current year, zero otherwise } \\ \text { ROA } & =\text { Net income deflated by total assets; }\end{aligned}$




$$
\begin{aligned}
\text { BM } & =\text { Book value of equity deflated by the market value of equity } \\
\text { STDRET } & =\text { The standard deviation of monthly stock return during the fiscal year } \\
\text { MARKET } & =\text { One if the firm listed in KSE, zero if the firm listed in KOSDAQ } \\
\text { YR } & =\text { Year dummy }
\end{aligned}
$$

\subsection{Descriptive statistics}

As been illustrated in Table 1, bond issuance and firm characteristics are summarized. After eliminating the top and bottom 1 percent outliers, observations of 8,079 were screened out. The mean (median) cost of debt (SPREAD) is $0.0271(0.0183)$ with a standard deviation of 0.0223 . The mean (median) international diversification (INTDIV) is $0.3071(0.1369)$ with a standard deviation of 0.2765 . It shows that the Korean market has a positively skewed in cost of debt and international diversification in that the mean value is larger than the median value. Prior studies argue that positive skewness of degree of internationalization (DOI) is similar to the U.S. market, indicating that DOI is 0.93 (0.66) but it is different from French market, indicating that DOI is 0.39 (0.43) (Reeb et al., 2001; Singh and Nejadmalayeri, 2004). The mean (median) of financial leverage (LEV) is 0.1690 (0.5013) with a standard deviation of 0.5028 . The mean (median) fixed asset ratio (ASSTR) is $0.1280(0.1691)$ with a standard deviation of 0.1943 . The mean (median) discretionary accruals (DA) is $0.0772(0.0603)$ with a standard deviation of 0.0829 . The mean (median) return of asset (ROA) is $0.1043(0.0265)$ with a standard deviation of 0.0104 . The mean (median) interest coverage (INTCOV) is 17.5593 (1.9727) with a standard deviation of 5.8739. The mean

\begin{tabular}{|c|c|c|c|c|c|c|c|c|c|c|c|c|}
\hline Variables & SPREAD & INTDIV & SIZE & LEV & ASSTR & DA & LOSS & ROA & INTCOV & $\mathrm{BM}$ & STDRET & MARKET \\
\hline SPREAD & 1.0000 & & & & & & & & & & & \\
\hline INTDIV & $\begin{array}{l}-0.0515 \\
(<.0001)\end{array}$ & 1.0000 & & & & & & & & & & \\
\hline SIZE & $\begin{array}{c}0.0294 \\
(0.0082)\end{array}$ & $\begin{array}{c}0.0831 \\
(<.0001)\end{array}$ & 1.0000 & & & & & & & & & \\
\hline LEV & $\begin{array}{c}0.2583 \\
(<.0001)\end{array}$ & $\begin{array}{c}0.0163 \\
(0.1434)\end{array}$ & $\begin{array}{c}0.1961 \\
(<.0001)\end{array}$ & 1.0000 & & & & & & & & \\
\hline ASSTR & $\begin{array}{c}-0.0899 \\
(<.0001)\end{array}$ & $\begin{array}{c}0.1272 \\
(<.0001)\end{array}$ & $\begin{array}{c}0.1111 \\
(<.0001)\end{array}$ & $\begin{array}{c}0.1221 \\
(<.0001)\end{array}$ & 1.0000 & & & & & & & \\
\hline DA & $\begin{array}{c}0.0971 \\
(<.0001)\end{array}$ & $\begin{array}{l}-0.0218 \\
(0.0506)\end{array}$ & $\begin{array}{l}-0.1590 \\
(<.0001)\end{array}$ & $\begin{array}{c}0.0699 \\
(<.0001)\end{array}$ & $\begin{array}{l}-0.1333 \\
(<.0001)\end{array}$ & 1.0000 & & & & & & \\
\hline LOSS & $\begin{array}{c}0.1949 \\
(<.0001)\end{array}$ & $\begin{array}{c}0.0358 \\
(0.0013)\end{array}$ & $\begin{array}{c}-0.1690 \\
(<.0001)\end{array}$ & $\begin{array}{c}0.2165 \\
(<.0001)\end{array}$ & $\begin{array}{l}-0.0022 \\
(0.8412)\end{array}$ & $\begin{array}{c}0.1499 \\
(<.0001)\end{array}$ & 1.0000 & & & & & \\
\hline ROA & $\begin{array}{c}-0.2552 \\
(<.0001)\end{array}$ & $\begin{array}{c}0.0128 \\
(0.2503)\end{array}$ & $\begin{array}{c}0.1790 \\
(<.0001)\end{array}$ & $\begin{array}{l}-0.2622 \\
(<.0001)\end{array}$ & $\begin{array}{c}0.0305 \\
(0.0062)\end{array}$ & $\begin{array}{l}-0.2451 \\
(<.0001)\end{array}$ & $\begin{array}{l}-0.7311 \\
(<.0001)\end{array}$ & 1.0000 & & & & \\
\hline INTCOV & $\begin{array}{l}-0.1770 \\
(<.0001)\end{array}$ & $\begin{array}{l}-0.0362 \\
(0.0011)\end{array}$ & $\begin{array}{c}0.0294 \\
(0.0082)\end{array}$ & $\begin{array}{l}-0.3156 \\
(<.0001)\end{array}$ & $\begin{array}{l}-0.0544 \\
(<.0001)\end{array}$ & $\begin{array}{l}-0.0439 \\
(<.0001)\end{array}$ & $\begin{array}{l}-0.2783 \\
(<.0001)\end{array}$ & $\begin{array}{c}0.3704 \\
(<.0001)\end{array}$ & 1.0000 & & & \\
\hline $\mathrm{BM}$ & $\begin{array}{c}0.0430 \\
(0.0001)\end{array}$ & $\begin{array}{l}-0.0531 \\
(<.0001)\end{array}$ & $\begin{array}{c}0.1889 \\
(<.0001)\end{array}$ & $\begin{array}{c}0.0016 \\
(0.8848)\end{array}$ & $\begin{array}{c}0.0432 \\
(0.0001)\end{array}$ & $\begin{array}{l}-0.1508 \\
(<.0001)\end{array}$ & $\begin{array}{l}-0.0474 \\
(<.0001)\end{array}$ & $\begin{array}{c}0.0252 \\
(0.0237)\end{array}$ & $\begin{array}{l}-0.0647 \\
(<.0001)\end{array}$ & 1.0000 & & \\
\hline STDRET & $\begin{array}{c}0.1133 \\
(<.0001)\end{array}$ & $\begin{array}{c}0.0132 \\
(0.2360)\end{array}$ & $\begin{array}{c}-0.1537 \\
(<.0001)\end{array}$ & $\begin{array}{c}0.1564 \\
(<.0001)\end{array}$ & $\begin{array}{l}-0.0440 \\
(<.0001)\end{array}$ & $\begin{array}{c}0.1150 \\
(<.0001)\end{array}$ & $\begin{array}{c}0.1165 \\
(<.0001)\end{array}$ & $\begin{array}{l}-0.1243 \\
(<.0001)\end{array}$ & $\begin{array}{c}-0.1181 \\
(<.0001)\end{array}$ & $\begin{array}{l}-0.1437 \\
(<.0001)\end{array}$ & 1.0000 & \\
\hline MARKET & $\begin{array}{c}0.0392 \\
(0.0004) \\
\end{array}$ & $\begin{array}{c}0.0481 \\
(<.0001) \\
\end{array}$ & $\begin{array}{c}0.5628 \\
(<.0001) \\
\end{array}$ & $\begin{array}{c}0.0860 \\
(<.0001) \\
\end{array}$ & $\begin{array}{c}0.0839 \\
(<.0001) \\
\end{array}$ & $\begin{array}{l}-0.1720 \\
(<.0001) \\
\end{array}$ & $\begin{array}{l}-0.1341 \\
(<.0001) \\
\end{array}$ & $\begin{array}{c}0.1313 \\
(<.0001) \\
\end{array}$ & $\begin{array}{c}0.0079 \\
(0.4754) \\
\end{array}$ & $\begin{array}{c}0.2673 \\
(<.0001) \\
\end{array}$ & $\begin{array}{l}-0.1373 \\
(<.0001) \\
\end{array}$ & 1.0000 \\
\hline
\end{tabular}
(median) book-to market ratio (BM) is 1.3227 (1.3554) with a standard deviation of 1.7179. The mean (median) standard deviation of stock return (STDRET) is 11.51 (16.0414) with a standard deviation of 19.2435.

Table 2. Pearson correlation matrix

Variable definition: refers to Table 1; The table provides Pearson correlation matrix between variables for the sample to test the relation between the costs of debt and independent variables

Table 2 reports the Pearson correlations for the variables listed in the test model. The main correlation between SPREAD and INTDIV is negative and significant, showing Pearson correlation of -0.0515 , suggesting that international diversification is negatively associated with cost of debt capital. A positive correlation between SPREAD and DA, showing Pearson correlation of 0.0971, has been observed, consistent with the argument that lenders may require higher level of interest rate to protect debt safety if borrowers tend to manipulate earnings (Francis et al., 2005). It is also observed that INTDIV has different correlations with LEV and DA, Pearson correlation of 0.0163 and -0.0218 for LEV and DA, respectively. This suggests that firms tend to select more debt financing for international diversification. Furthermore, BM has negative correlation with INTDIV, Pearson correlation of - 0.0531 , and ASSTR has positive correlation with INTDIV, Pearson correlation of 0.1272 , implying that when the higher the market price of the firms' internationalization activities is, the higher firms' fixed assets could be. Hence, the internationalization activities can be viewed as good news for firms. Lastly, SIZE and MARKET are both positively correlated with INTDIV, Pearson correlation of 0.0831 and 0.0481 , respectively, indicating that larger firms are more likely to expand their global operation. 


\section{Empirical Results}

The regression results presented in the Tables 3 to 6 are based on pooled regression analysis. The statistical significance of the estimated coefficients is estimated using the clustering analysis which clusters standard errors by firms. Petersen (2009) compares different regression estimation approaches and addresses the issue of crosssectional and time-series dependence of the residuals for panel data. Clustered standard errors from pooled regressions provide unbiased estimates of the true standard errors, whereas standard errors from both pooled OLS regressions and those from Fama-Macbeth regressions are biased. This pooled regression also has been used in Elliott et al. (2010) and Kim et al. (2012).

\subsection{International Diversification and Cost of Debt}

Table 3. Regression Analysis between Internationalization and Cost of Debt

\begin{tabular}{|c|c|c|c|c|c|}
\hline \multirow{3}{*}{ variable } & \multirow{3}{*}{$\begin{array}{l}\text { Predicted } \\
\text { sign }\end{array}$} & \multicolumn{4}{|c|}{ Dependent variable: Spread } \\
\hline & & \multicolumn{2}{|c|}{ Section A } & \multicolumn{2}{|c|}{ Section B } \\
\hline & & Coeff. & t-stat & Coeff. & t-stat \\
\hline Intercept & $?$ & 0.0122 & $1.68 *$ & \multirow[t]{2}{*}{0.0123} & \multirow[t]{2}{*}{$1.7 *$} \\
\hline INTDIV & - & -0.0036 & $-2.63 * * *$ & & \\
\hline INTDIV_D & - & & & -0.0028 & $-3.42 * * *$ \\
\hline SIZE & - & 0.0000 & -0.12 & 0.0000 & -0.08 \\
\hline LEV & + & 0.0325 & $11.85 * * *$ & 0.0324 & $11.84 * * *$ \\
\hline ASSTR & - & -0.0206 & $-6.22 * * *$ & -0.0201 & $-6.071 * * *$ \\
\hline DA & + & 0.0136 & $3.13 * * *$ & 0.0133 & $3.06 * * *$ \\
\hline LOSS & + & 0.0014 & 1.41 & 0.0014 & 1.43 \\
\hline ROA & - & -0.0416 & $-7.59 * * *$ & -0.0417 & $-7.61 * * *$ \\
\hline INTCOV & - & -0.0001 & $-2.8 * * *$ & -0.0001 & $-2.84 * * *$ \\
\hline $\mathrm{BM}$ & + & 0.0012 & $3.47 * * *$ & 0.0013 & $3.52 * * *$ \\
\hline STDRET & + & 0.0001 & $3.35 * * *$ & 0.0001 & $3.29 * * *$ \\
\hline MARKET & $?$ & 0.0027 & $2.54 * *$ & 0.0027 & $2.56^{* *}$ \\
\hline$\sum \mathrm{YR}$ & & \multicolumn{2}{|c|}{ Included } & \multicolumn{2}{|c|}{ Included } \\
\hline \multicolumn{2}{|c|}{ F-value } & \multicolumn{2}{|c|}{$79.59 * * *$} & \multicolumn{2}{|c|}{$79.63 * * *$} \\
\hline \multicolumn{2}{|c|}{$\mathrm{R}^{2}$} & \multicolumn{2}{|c|}{0.2181} & \multicolumn{2}{|c|}{0.2190} \\
\hline \multicolumn{2}{|c|}{$\mathrm{N}$} & \multicolumn{2}{|c|}{8,079} & \multicolumn{2}{|c|}{8,079} \\
\hline
\end{tabular}

Statistical significance of the reported coefficients is based on the Petersen (2009) clustered standard errors correcting for within-firm and within-year correlations. Variable definition: refers to Table $1 ; * * *, * *, *$ denote significance at the $1 \%, 5 \%$ and $10 \%$ level, respectively, for a two-tailed test

Table 3 reports the main regression results of international diversification on the cost of debt on. The interest yield spreads on the financial statement is used as a measure of the cost of debt financing, where SPREAD is defined as the difference between interest rate and 3-years-maturity Treasury bond yield in the same year. In this part, our main independent variable of international diversification is measured by the continuous variable, INTDIV, and dummy variable, INTDIV_D, indicating 1 if INTDIV is greater than median value. Table 3 shows that the coefficients on both INTDIV and INTDIV_D are negative and significant at the $1 \%$ level, $-0.0036(\mathrm{t}$-stat $=-2.63)$ and -0.0028 (t-stat=-3.42), respectively. This results support our first hypothesis, indicating that internationally diversified firms are more likely to reduce the cost of debt capital. The results of the control variables are also qualitatively consistent with prior studies. The coefficient estimates on SIZE, ASSTR, ROA, and INTCOV are negative and significant in the regressions, while the coefficient estimates on LEV, DA, LOSS, BM, STDRET are positive in the regression. 


\subsection{International Diversification, Cost of Debt and Information Environment}

Table 4. Regression Analysis between Internationalization and Cost of Debt conditional on Analyst Covered

\begin{tabular}{|c|c|c|c|c|c|}
\hline \multirow{3}{*}{ variable } & \multirow{3}{*}{$\begin{array}{l}\text { Predicted } \\
\text { sign }\end{array}$} & \multicolumn{4}{|c|}{ Dependent variable: Spread } \\
\hline & & \multicolumn{2}{|c|}{ Firms with Analyst following } & \multicolumn{2}{|c|}{ Firms without Analyst following } \\
\hline & & Coeff. & t-stat & Coeff. & t-stat \\
\hline Intercept & $?$ & 0.0175 & $1.88 *$ & -0.0137 & -1.22 \\
\hline INTDIV & - & -0.0068 & $-3.72 * * *$ & -0.0018 & -1.01 \\
\hline SIZE & - & -0.0006 & -1.18 & 0.0016 & $2.48 * *$ \\
\hline LEV & + & 0.0385 & $9.51 * * *$ & 0.0292 & $8.51 * * *$ \\
\hline ASSTR & - & -0.0171 & $-4.04 * * *$ & -0.0215 & $-5.2 * * *$ \\
\hline DA & + & 0.0113 & $1.72 *$ & 0.0134 & $2.39 * *$ \\
\hline LOSS & + & 0.0015 & 0.93 & 0.0014 & 1.1 \\
\hline ROA & - & -0.0214 & $-2.53 * *$ & -0.0456 & $-6.87 * * *$ \\
\hline INTCOV & - & 0.0000 & -0.78 & -0.0001 & $-2.94 * * *$ \\
\hline $\mathrm{BM}$ & + & 0.0020 & $3.99 * * *$ & 0.0004 & 0.97 \\
\hline STDRET & + & 0.0001 & 1.29 & 0.0001 & $2.99 * * *$ \\
\hline MARKET & $?$ & 0.0012 & 0.78 & 0.0024 & $1.87 *$ \\
\hline \multicolumn{2}{|l|}{$\sum \mathrm{YR}$} & \multicolumn{2}{|c|}{ Included } & \multicolumn{2}{|c|}{ Included } \\
\hline \multicolumn{2}{|c|}{ F-value } & \multicolumn{2}{|c|}{$39.34 * * *$} & \multicolumn{2}{|c|}{$47.67 * * *$} \\
\hline \multicolumn{2}{|c|}{$\mathrm{R}^{2}$} & \multicolumn{2}{|c|}{0.2349} & \multicolumn{2}{|c|}{0.2085} \\
\hline \multicolumn{2}{|c|}{$\mathrm{N}$} & \multicolumn{2}{|c|}{3,092} & \multicolumn{2}{|c|}{4,987} \\
\hline
\end{tabular}

Variable definition: refers to Table 1;

$* * *, * *, *$ denote significance at the $1 \%, 5 \%$ and $10 \%$ level, respectively, for a two-tailed test

Table 4 presents the regression results of INTDIV on SPREAD after incorporating the effects of information environment, which is measured by analyst coverage. This paper employ analyst coverage as a proxy for good information environment. Our subsample composes of firms with analyst followings and firms without analyst followings, 3,092 and 4,987 firm-year data, respectively. The coefficient on INTDIV for the subsample of firmyear observations with analyst followings is negative and significant, -0.0068 (t-statistic $=-3.72$ ), while the coefficient for firms without analyst coverage is statistically insignificant, -0.0018 (t-statistic $=-1.01$ ). This finding indicates that the effect of international diversification on debt capital savings are working only for firms with analyst followings, implying that good information environment is a key factor for the positive economic effect of international diversification in the Korean debt market.

\subsection{International Diversification, Cost of Debt and Audit Quality}

Table 5 presents the empirical result of $\mathrm{H} 3$. To test for the impact of audit quality, firms audited by one of Big 4 accounting firms are regarded as providing higher audit quality. After eliminating those firms with no auditor information, the sample is classified as high audit quality (Big 4 audited firms) and low audit quality (non-Big 4 audited firms) subsamples, 4,468 and 3,609 firm-year observation, respectively. From the test result, the coefficient on INTDIV for the Big4 subsample is negative and significant, -0.0034 (t-statistic $=-1.75$ ), while the coefficient on INTDIV for the non-Big4 subsample is statistically insignificant, -0.0028 (t-statistic $=-1.61$ ). This is in supportive of $\mathrm{H3}$, suggesting that the economic effect of international diversification on debt capital savings is working only for the firms with higher audit quality. It implies that audit quality is another key factor for positive role of international diversification in debt markets.

Meanwhile, the coefficient on DA for non-Big4 subset is positive and significant, 0.0167 (t-statistic $=2.76)$, while coefficient on DA for Big4 is statistically insignificant, $0.0096(\mathrm{t}$-statistic $=1.56)$. This is consistent with prior research that firms with higher audit quality are likely to exhibit lower discretionary accruals, which lends credibility to our research model and empirical results. 
Table 5. Regression Analysis between Internationalization and Cost of Debt conditional on Big4 audited firms

\begin{tabular}{|c|c|c|c|c|c|}
\hline \multirow{3}{*}{ variable } & \multirow{3}{*}{$\begin{array}{l}\text { Predicted } \\
\text { sign }\end{array}$} & \multicolumn{4}{|c|}{ Dependent variable: Spread } \\
\hline & & \multicolumn{2}{|c|}{ Firms audited by Big4 } & \multicolumn{2}{|c|}{ Firms audited by Non-Big4 } \\
\hline & & Coeff. & t-stat & Coeff. & t-stat \\
\hline Intercept & $?$ & 0.0066 & 0.75 & 0.0229 & $1.75^{*}$ \\
\hline INTDIV & - & -0.0034 & $-1.75^{*}$ & -0.0028 & -1.61 \\
\hline SIZE & - & -0.0002 & -0.38 & -0.0002 & -0.3 \\
\hline LEV & + & 0.0416 & $10.95 * * *$ & 0.0234 & $6.39 * * *$ \\
\hline ASSTR & - & -0.0170 & $-4.02 * * *$ & -0.0240 & $-5.21 * * *$ \\
\hline DA & + & 0.0096 & 1.56 & 0.0167 & $2.76^{* * *}$ \\
\hline LOSS & + & 0.0012 & 0.84 & 0.0016 & 1.16 \\
\hline ROA & - & -0.0301 & $-3.59 * * *$ & -0.0470 & $-6.86^{* * *}$ \\
\hline INTCOV & - & -0.0001 & $-2.03 * *$ & -0.0001 & $-2.06 * *$ \\
\hline $\mathrm{BM}$ & + & 0.0014 & $3.09 * * *$ & 0.0009 & $1.69 *$ \\
\hline STDRET & + & 0.0001 & $2.69 * * *$ & 0.0001 & $1.99^{* *}$ \\
\hline MARKET & $?$ & 0.0030 & $2 * *$ & 0.0027 & $2.08^{* *}$ \\
\hline \multicolumn{2}{|l|}{$\sum \mathrm{YR}$} & \multicolumn{2}{|c|}{ Included } & \multicolumn{2}{|c|}{ Included } \\
\hline \multicolumn{2}{|c|}{ F-value } & \multicolumn{2}{|c|}{$51.84 * * *$} & \multicolumn{2}{|c|}{$38.55 * * *$} \\
\hline \multicolumn{2}{|c|}{$\mathrm{R}^{2}$} & \multicolumn{2}{|c|}{0.2325} & \multicolumn{2}{|c|}{0.2168} \\
\hline \multicolumn{2}{|c|}{$\mathrm{N}$} & \multicolumn{2}{|c|}{4,468} & \multicolumn{2}{|c|}{3,608} \\
\hline
\end{tabular}

Variable definition: refers to Table 1 ;

$* * *, * *, *$ denote significance at the $1 \%, 5 \%$ and $10 \%$ level, respectively, for a two-tailed test

\subsection{Additional analysis}

$$
\begin{aligned}
\text { SPREAD }_{t+1}=\alpha_{1} & +\beta_{1} F_{-} S A L E S_{t}+\beta_{2} D_{-} S A L E S_{t}+\beta_{3} \operatorname{SIZE}_{t}+\beta_{4} L_{E V}+\beta_{5} \text { ASSTR }_{t}+\beta_{6} \text { DA }_{t}+\beta_{7} \text { LOSS }_{t} \\
& +\beta_{8} R O A_{t}+\beta_{9} \text { INTCOV }_{t}+\beta_{10} B M_{t}+\beta_{11} \text { STDRET }_{t}+\beta_{12} \text { MARKET }_{t}+\Sigma Y R+\varepsilon_{t}
\end{aligned}
$$

Researchers tend to use domestic earning and foreign earning as an actual numerical measure of the international diversification (Bodnar and Weintrop 1997; Denis et al. 2002.). However, there is a data limitation of geographic earnings in Korea. In this regards, domestic sales and foreign sales are utilized as an alternative measure for international diversification in the sense that sales are often considered the key value driver for earnings (Penman 2004). In this section, as an additional analysis, this test employs domestic sales and foreign sales respectively as independent variables and examines which geographic sales are more important in affecting SPREAD, cost of debt capital. Table 6 show that the coefficients on foreign sales and domestic sales are -0.0041 (t-statistics $=-3.32$ ) and -0.0020 (t-statistics=-1.88), respectively, showing that coefficient on foreign sales is more negative than that of domestic sales. This suggests that foreign sales are more important in reducing the cost of debt capital than domestic sales, which is consistent with our main research question, H1. 
Table 6. Regression Analysis of the impact of Foreign Sales and Domestic Sales on Cost of Debt

\begin{tabular}{lcl}
\hline & Coeff. & t-stat \\
\hline Intercept & 0.0182 & $2.59^{* * *}$ \\
F_SALES & -0.0041 & $-3.32^{* * *}$ \\
D_SALES & -0.0020 & $-1.88^{*}$ \\
SIZE & -0.0003 & -0.71 \\
ASSTR & -0.0213 & $-6.71^{* * *}$ \\
LOSS & 0.0018 & $1.87^{*}$ \\
MARKET & 0.0025 & $2.37^{* *}$ \\
ABSDA & 0.0102 & $2.63^{* * *}$ \\
LEV & 0.0333 & $11.99^{* * *}$ \\
BM & 0.0012 & $3.4^{* * *}$ \\
INTCOV & 0.0000 & -1.45 \\
ROA & -0.0365 & $-7.49^{* * *}$ \\
STDRET & 0.0001 & $3.24 * * *$ \\
EYR & \multicolumn{2}{c}{ Included } \\
\hline \multicolumn{2}{c}{$\mathrm{N}$} & 0.2238 \\
\hline
\end{tabular}

F_SALES = Foreign sales deflated by prior total assets; D_SALES = Domestic sales deflated by prior total assets. Other variables definition refers to Table 1

$* * *, * *, *$ denote significance at the $1 \%, 5 \%$ and $10 \%$ level, respectively, for a two-tailed test.

\section{Research Limitation and Conclusion}

There are two research limitations of this paper. In the first place, the variable to measure international diversification is limited due to the data availability in Korea. Second, this paper uses aggregate international data without considering the difference by country, which possibly could bias our result. Despite the limitations discussed above, this paper contributes to the current literature of international diversification and cost of debt by suggesting the positive economic benefits of internationalization in terms of debt cost reduction in Korean capital market. Furthermore, it provides the first evidence that good information environment as well as high audit quality play a significant role in generating positive effect of internationalization on cost of debt capital.

\section{References}

Agmon, T., and Lessard, D. R. (1977). Investor Recognition of Corporate International Diversification. Journal of Finance 32(4): 1049-1055.

Aliber, R. Z. (1984). International Banking: A Survey. Journal of Money, Credit and Banking 16(4): 661-678.

Anderson, T.M. (2004). Managing strategic innovation and change: a collection of readings. New York: Oxford University Press.

Boatsman, J. R., Behn, B. K., and Patz, D. H. (1993). A test of the Use of Geographical Segment Disclosures. Journal of Accounting Research 31:46-64.

Bodnar, G. M., and Weintrop, J. (1997). The valuation of the foreign income of us multinational firms: A growth opportunities perspective. Journal of Accounting and Economics 24 (1):69-97.

Bodnar, G. M., Hwang, L. S., and Weintrop, J. (2003). The value relevance of foreign income: An Australian, Canadian and British Comparison. Journal of International Financial Management \& Accounting 14(3): 171-193.

Callen, J. L., Hope, O. K., and Segal, D. (2005). Domestic and foreign earnings, stock return variability, and the impact of investor sophistication. Journal of Accounting Research 43 (3):377-412.

Cha, S. M., Chung, J. H., and Yoo, Y. K. (2010). Corporate international Diversification and Cost of Equity Capital: Korean Evidence. Korean Management Research, 39: 157-175

Christophe, S. E. (2002). The value of U.S. MNC earnings changes from foreign and domestic operations. Journal of Business 75 (1):67.

Datta, S., Iskandar-Datta, M., and Patel, A. (1999). The Market's Pricing of Debt IPOs. Journal of Applied Corporate Finance 12(1): 86-91.

Denis, D. J., Denis, D. K., and Yost, K. (2002). Global diversification, industrial diversification, and firm value. Journal of Finance 57 (5):1951-1979.

Diamond, D. (1989). Reputation Acquisition in Debt Markets. The Journal of Political Economy 97(4):828-862. 
Duru, A., and Reeb, D. M. (2002). International diversification and analysts' forecast accuracy and bias. The Accounting Review 77 (2):415-433.

Elliott, J. A., Ghosh, A., and Moon, D. (2010). Asymmetric valuation of sustained growth by bond- and equity- holders. Review of Accounting Studies 15(4): 833-878.

Errunza V. R., and Senbet, L. W. (1981). The Effects of International Operations on the Market Value of the Firm: Theory and Evidence. The Journal of Finance 36(2): 401-417.

Francis, J., LaFond, R. Olsson, P., and Schipper, K. (2005). The market pricing of accruals quality. Journal of Accounting and Economics 39 (2):295-327.

Fatemi, A. M. (1984). Shareholder Benefits from Corporate International Diversification. Journal of Finance 39(5):13251344.

He, J., and Ng, L. (1998). The Foreign Exchange Exposure of Japanese Multinational Corporations. Journal of Finance 53(2): 733-753.

Herrmann, D., and W. B. Thomas. An analysis of segment disclosures under SFAS No. 131 and SFAs No. 14. Accounting Horizon 14 (3): 287-302.

Hope, O.K., Kang, T., Thomas, W. B., and Vasvari, F. (2008). Pricing and mispricing effects of SFAS 131. Journal of Business Finance \& Accounting 35(3): 281-306.

Hope, O.K., and Thomas, W. B. (2008). Managerial empire building and firm disclosure. Journal of Accounting Research 46 (3):591-626.

Kedia, S., and Mozumdar, A. (2002). Performance Impact of Employee Stock Options. Working Paper, Harvard Business School.

Khurana, I. K., Pereira, R., and Raman, K. K. (2003). Does analyst behavior explain market mispricing of foreign earnings for U. S. multinational firms? Journal of Accounting, Auditing \& Finance 18(4): 453-478.

Lee, Y.J. (2008). The effects of employee stock options on credit ratings. The Accounting Review 83 (5):1273-1314.

Lee, K. C., and Kwok, C. C. Y. (1988). Multinational Corporations vs. Domestic Corporations: International Environmental Factors and Determinants of Capital Structure. Journal of International Business Studies 19(2): 195-217.

Lessard, D. R. (1973). International portfolio diversification: a multivariate analysis for a group of Latin American countries. Journal of Finance 28(3):619-633.

Levy, H., and Sarnet, M. (1970). International Diversification of Investment Portfolios. The American Economic Review 60(4): 668-675.

Mansi, S. A., and Reeb, D. M. (2002). Corporate diversification: What gets discounted? Journal of Finance 57 (5):21672183.

Penman, S. (2004). Financial Statement Analysis and Security Valuation. Irwin/McGraw-Hill, Boston, MA.

Petersen, M. (2009). Estimating standard errors in finance panel data sets: Comparing approaches. Review of Financial Studies 22:435-480.

Piostroski, J.D., and Roulstone, B.T. (2004). The Influence of Analysts, Institutional Investors, and Insiders on the Incorporation of Market, Industry, and Firm-Specific Information into Stock Prices. The Accounting Review 79(4): 1119-1151

Pittman, J.A., and Fortin, S. (2004). Auditor choice and the cost of debt capital for newly public firms. Journal of Accounting and Economics 37(1):113-136.

Reeb, M. D., Sattar, M. A. and Allee, J. (2001). Firm Internationalization and the Cost of Debt Financing: Evidence from Non-Provisional Publicly Traded Debt. Journal of Financial and Quantitative Analysis 36(3): 395-414.

Sanchez-Ballesta, J. P., and Garcia-Meca, E. (2011). Ownership Structure and the Cost of Debt. European Accounting Review 20(2): 389-416.

Sharked, I. (1986). “Are Multinational Corporations Safer?” Journal of International Business Studies 16: 83-106.

Singh, M., and Nejadmalayeri, A. (2004). Internationalization, capital structure, and cost of capital: evidence from French corporations. Journal of Multinational Financial Management 14(2): 153-169.

Sullivan, D. (1994). Measuring the degree of internationalization of a firm. Journal of International Business Studies 25:325342.

Thomas, W. B. (1999). A test of the market's mispricing of domestic and foreign earnings. Journal of Accounting and Economics 28 (3):243-267. 